\title{
Pemberian Nutrisi pada Pasien dengan Penyakit Kritis di Ruang Perawatan Intensif Anak RS. Gipto Mangunkusumo
}

\author{
Irene Yuniar, Abdul Latief, Yoga Devaera, Suci Fitrianti \\ Departemen Ilmu Kesehatan Anak Fakultas Kedokteran Universitas Indonesia/ RS Dr. Cipto \\ Mangunkusumo, Jakarta
}

\begin{abstract}
Latar belakang. Anak yang dirawat di PICU (pediatric intensive care unit) Anak cenderung untuk mengalami malnutrisi sejak masuk atau selama perawatan. Hal ini akan memperberat penyakit dasar dan komplikasinya, memperpanjang lama rawat, serta meningkatkan mortalitas. Perhitungan kebutuhan kalori yang tepat serta pemberian nutrisi yang adekuat dan sesuai merupakan target perawatan anak di PICU. Baik underfeeding ataupun overfeeding dapat terjadi di PICU Anak selama perawatan.

Tujuan. Mengetahui status gizi awal pasien masuk PICU Anak, pola pemberian nutrisi, serta faktor yang memengaruhi pemberian nutrisi pada anak yang di PICU.

Metode. Penelitian potong lintang dengan menggunakan data rekam medis pasien yang dirawat di PICU Anak dalam kurun waktu 3 bulan. Didapatkan 45 subjek ikut serta. Dari 45 data pasien didapatkan 127 peresepan untuk menilai keseuaian peresepan dengan pemberian nutrisi pada pasien.

Hasil. Penelitian ini mendapatkan 47,8\% pasien malnutrisi saat awal masuk PICU Anak, 8,7\% mengalami obesitas. Pada hari kedua perawatan, $41,3 \%$ pasien mulai mendapat nutrisi. Underfeeding terjadi pada pemberian kalori, protein, dan lemak. Selain itu, 44,9\% underfeeding terjadi karena perdarahan saluran cerna.

Kesimpulan. Pemberian nutrisi pada pasien yang dirawat di PICU Anak merupakan hal yang sangat penting. Perlu perhitungan kebutuhan nutrisi yang cermat, pemberian nutrisi tepat yang sesuai kebutuhan pasien agar tidak terjadi malnutrisi yang lebih berat lagi. Sari Pediatri 2014;16(4):254-9.
\end{abstract}

Kata kunci : status nutrisi, underfeeding, overfeeding, kondisi kritis

A

nak yang dirawat di ruang rawat intensif (Pediatric Intensive Care Unit/ PICU) sangat berisiko mengalami malnutrisi yang dapat disebabkan karena penyakitnya

\section{Alamat korespondensi:}

Dr. Irene Yuniar, Sp.A. Staf Pediatri Gawat Darurat FKUI-RSCM, Jl. Diponegoro No.71, Jakarta. Email: irene.tambunan@yahoo.co.id sendiri atau karena proses perawatan di ruang rawat intensif. Malnutrisi terjadi sekitar 15\%-25\% anak pada saat awal masuk PICU. Malnutrisi ini akan mengakibatkan peningkatan morbiditas dan mortalitas, lama rawat, lama pasien memakai ventilator, serta biaya perawatan. ${ }^{1-4}$

Respon tubuh terhadap stres ditandai dengan peningkatan mediator pro-inflamasi yang 
mengakibatkan peningkatan hormon counterregulatory seperti katekolamin, glukagon, dan glukokortikoid dalam serum yang pada akhirnya akan mengubah metabolisme karbohidrat, protein, dan lemak. ${ }^{3,4}$ Kondisi stres meningkatkan proses katabolisme yang memerlukan energi dalam jumlah besar sehinga pasien mudah mengalami malnutrisi energi protein (MEP). Banyak protein yang dipakai untuk memperbaiki jaringan yang rusak karena proses inflamasi. Selain dari hal tersebut di atas, disebutkan bahwa pemberian nutrisi pada pasien yang dirawat tidak sesuai dengan peresepan nutrisi sehingga membuat anak semakin mengalami MEP. Hal ini disebabkan karena beberapa faktor seperti restriksi cairan, kondisi anak tidak stabil, perdarahan saluran cerna, dan lain sebagainya. ${ }^{1,3}$ Diperlukan evaluasi nutrisi yang baik sehingga malnutrisi pada pasien di PICU dapat dihindari.

Tujuan penelitian ini adalah. mengetahui status nutrisi awal saat pasien masuk PICU, pola pemberian nutrisi sesuai kebutuhan pasien, selisih peresepan dan pemberian nutrisi serta faktor yang memengaruhinya.

\section{Metode}

Penelitian potong lintang dengan pengambilan subjek secara consecutive sampling. Penelitian dilakukan di PICU FKUI-RSCM yang mempunyai 11 tempat tidur yang terdiri atas 3 tempat tidur neonatus pasca bedah serta 8 tempat tidur pediatrik. Penelitian dilakukan selama 3 bulan (Februari-April 2014). Digunakan data rekam medis pasien pada tahun sebelumnya (tahun 2013) karena pada September 2013 didapatkan wabah infeksi di PICU sehingga dipindahkan dengan kapasitas yang dikurangi menjadi 6 tempat tidur pediatrik dan 2 tempat tidur neonatus.

Dilakukan pencatatan nama, nomor rekam medik, usia dan tanggal lahir, tanggal masuk PICU, diagnosis masuk PICU (bedah atau non bedah), berat badan, tinggi badan, perhitungan antropometri, penentuan status gizi, perhitungan kebutuhan nutrisi per hari, perhitungan kebutuhan kalori berdasarkan BMR ditambah dengan faktor stres, perhitungan kebutuhan protein dan lemak berdasarkan recommended dietary allowance $(\mathrm{RDA})$, pencatatan pemberian kalori, protein,

Tabel 1. Perhitungan kebutuhan BMR berdasarkan Schofield W ${ }^{5}$

\begin{tabular}{lc}
\hline Jenis kelamin & $\begin{array}{c}\text { Perkiraan REE per hari } \\
(\text { Kkal/hari })\end{array}$ \\
\hline $\begin{array}{l}\text { Laki-laki (tahun) } \\
0-3\end{array}$ & $(0,167 \times \mathrm{BB})+(15,174 \times \mathrm{TB})-617,6$ \\
$3-10$ & $(19,59 \times \mathrm{BB})+(1,303 \times \mathrm{TB})+414,9$ \\
$10-18$ & $(16,25 \times \mathrm{BB})+(1,372 \times \mathrm{TB})+515,5$ \\
Perempuan (tahun) & \\
$0-3$ & $(16,252 \times \mathrm{BB})+(10,232 \times \mathrm{TB})-413,5$ \\
$3-10$ & $(16,969 \times \mathrm{BB})+1,618 \times \mathrm{TB})+371,2$ \\
$10-18$ & $(8,365 \times \mathrm{BB})+(4,65 \times \mathrm{TB})+200$ \\
\hline
\end{tabular}

Keterangan : $\mathrm{BB}=$ berat badan, $\mathrm{TB}=$ tinggi badan

Tabel 2. Perkiraan besar faktor stres ${ }^{2}$

\begin{tabular}{lc}
\hline Kondisi klinis & Faktor stres \\
\hline Puasa & 0,9 \\
Demam & $12 \%$ setiap kenaikan suhu 1 derajat C \\
Gagal jantung & $1,15-1,25$ \\
Bedah mayor & $1,2-1,3$ \\
Sepsis & $1,4-1,5$ \\
Luka bakar & $1,5-2,0$ \\
ICU dengan ventilator & 1,0 \\
\hline
\end{tabular}


dan lemak per hari serta alasan bila nutrisi tidak dapat diberikan sesuai peresepan. Perhitungan BMR yang dipakai berdasarkan rumus Schofield W (Tabel 1). ${ }^{5}$

Penilaian status gizi secara antropometris dilakukan dengan mengukur berat badan dengan alat bed scale dan tinggi badan dengan alat meteran. Data berat dan tinggi badan pasien akan diisi dalam grafik. Untuk pasien 1 bulan sampai 5 tahun digunakan grafik World Health Organization (WHO) 2006, sedangkan di atas 5 tahun digunakan grafik Centre for Disease Control and Prevention (CDC) 2000. Pengelompokan status gizi menjadi gizi buruk, kurang, normal, overweight serta obesitas berdasarkan kriteria Waterlow yang disadur dari Asuhan Nutrisi Pediatrik (Pediatric Nutrition Care) Rekomendasi Unit Kerja Koordinasi (UKK) Nutrisi dan Penyakit Metabolik IDAI tahun $2011 .^{6}$

Pencatatan dilakukan oleh dietisien PICU selama jam kerja. Underfeeding didefinisikan sebagai pemberian nutrisi per hari kurang dari $90 \%$ target yang akan dicapai. Sebaliknya, overfeeding didefinisikan sebagai pemberian nutrisi $>110 \%$ target yang akan dicapai. ${ }^{1,4}$

Kriteria inklusi adalah semua pasien yang masuk ke PICU berusia 1 bulan -18 tahun. Kriteria eksklusi adalah pasien dengan pencatatan nutrisi yang tidak lengkap (tidak ada perhitungan kebutuhan nutrisi serta penilaian 24 jam berikutnya). Perhitungan kebutuhan nutrisi pada pasien dengan kondisi kritis menggunakan formula:,

Kebutuhan energi = Resting energy expenditure (REE) $\mathrm{x}$ faktor aktivitas $\mathrm{x}$ faktor stres

Perhitungan besar faktor stres tertera pada Tabel 2. ${ }^{2}$ Aktivitas pasien di PICU sangat terbatas, sehingga kebutuhan energi sering dihitung berdasarkan REE dan faktor stres saja. ${ }^{2}$ Kebutuhan protein dihitung berdasarkan kelompok umur. Untuk anak berusia 0-2 tahun diperlukan protein $2-3 \mathrm{~g} / \mathrm{kg}$ berat badan (BB)/ hari, 2-13 tahun 1,5-2 g/kgBB/ hari, dan 13-18 tahun $1,5 \mathrm{~g} / \mathrm{kgBB} /$ hari. ${ }^{2,4}$ Data yang dikumpulkan diolah dengan menggunakan SPSS 15.0

\section{Hasil}

Selama 3 bulan penelitian, terdapat 63 pasien pediatrik yang dirawat di PICU, 18 pasien pencatatan tidak lengkap sehingga hanya 45 pasien yang diikutsertakan dalam penelitian ini. Dari 45 pasien didapatkan 127 peresepan nutrisi yang akan dievaluasi selanjutnya. Sebaran dan karakteristik pasien tertera pada Tabel 3.

Setelah status gizi ditentukan, dihitung kebutuhan kalori berdasarkan BMR sesuai usia ditambahkan dengan faktor stres yang terjadi pada masing-masing pasien. Selain itu, dihitung kebutuhan protein dan lemak sesuai RDA untuk masing-masing kelompok umur. Pemberian kalori, pada saat pasien dirawat dengan menghitung rata-rata pemberian kalori per hari, dibandingkan dengan kebutuhan kalori berdasarkan BMR dan faktor stres tertera pada Tabel 4. Tabel ini juga memperlihatkan persentasi pemberian lemak dan protein dibandingkan dengan RDA protein

Tabel 3. Karakteristik subjek penelitian $(n=45)$

\begin{tabular}{lcc}
\hline Karakteristik & $\begin{array}{c}\text { Jumlah } \\
\text { (n) }\end{array}$ & $\%$ \\
\hline Kelompok umur & & \\
1 bulan -1 tahun & 15 & 33,3 \\
$>1-5$ tahun & 12 & 26,7 \\
6-12 tahun & 11 & 24,4 \\
13-18 tahun & 7 & 15,6 \\
Jenis kelamin & & \\
Laki-laki & 30 & 66,7 \\
Perempuan & 15 & 33,3 \\
Jenis kasus & & \\
Bedah & 13 & 28,9 \\
Non bedah & 32 & 71,1 \\
Status gizi & & \\
Buruk & 1 & 2,2 \\
Kurang & 22 & 48,9 \\
Normal & 17 & 37,8 \\
Overweight & 1 & 2,2 \\
Obesitas & 4 & 8,9 \\
Pemberian nutrisi dimulai hari ke- & & \\
1 & 12 & 26,7 \\
2 & 19 & 42,2 \\
3 & 12 & 26,7 \\
4 & 2 & 4,4 \\
Lama rawat (hari) & & \\
$<72$ jam & 29 & 64,4 \\
$\geq 72$ jam & 16 & 35,6 \\
\hline
\end{tabular}

Tabel 4. Persentasi kalori terhadap BMR dan aktivitas protein dan lemak terhadap RDA

\begin{tabular}{lccc}
\hline Persen dari target & $<90 \%$ & $90-110 \%$ & $>110 \%$ \\
\hline Kalori $(\mathrm{n}=45)$ & 30 & 7 & 8 \\
Protein $(\mathrm{n}=45)$ & 39 & 5 & 1 \\
Lipid $(\mathrm{n}=45)$ & 27 & 11 & 7 \\
\hline
\end{tabular}


dan lemak untuk masing-masing kelompok umur.

Pada 45 pasien penelitian didapatkan 127 peresepan nutrisi. Selisih peresepan dan pemberian kalori dan protein tertera pada Gambar 1 dan 2.

Terdapatnya perbedaan selisih kalori yang diberikan dengan yang dibutuhkan terutama disebabkan adanya penyulit pemberian nutrisi enteral. Ditemukan lebih dari 1 penyulit pemberian enteral. Ditemukan 69 penyulit enteral dari 45 pasien yang menyebabkan

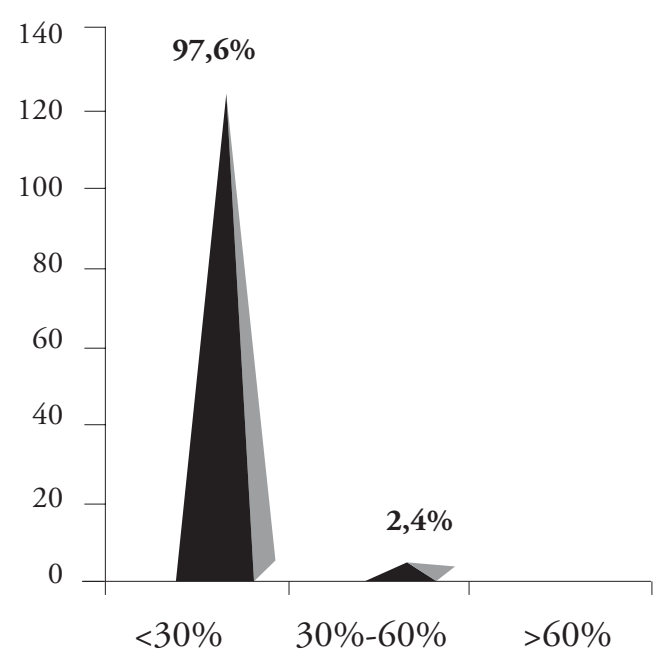

Gambar 1. Selisih antara peresepan dan pemberian kalori pada pasien yang dirawat di PICU

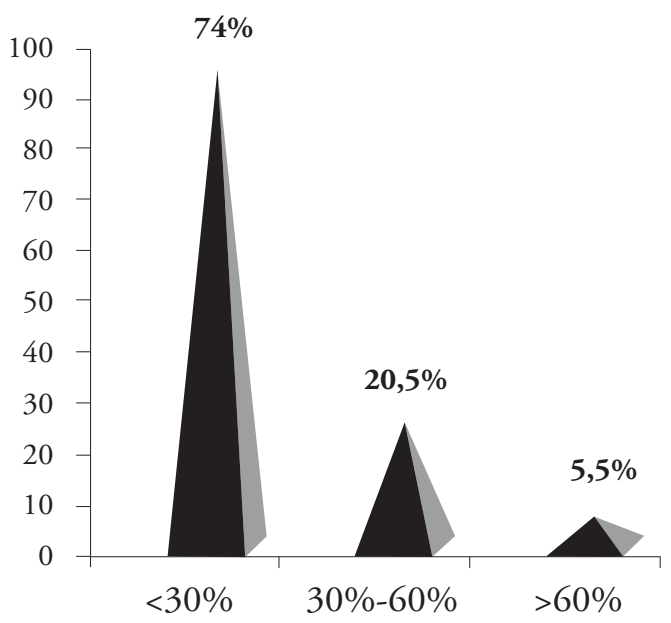

Gambar 2. Selisih antara peresepan pemberian protein pada pasien yang dirawat di PICU pemberian nutrisi hanya dapat diberikan secara parenteral. Jenis penyebab penyulit enteral antara lain diare (10), hipoksia akut (1), kembung (3), muntah (3), penurunan kesadaran (1), perdarahan gusi (2), perdarahan ssaluran cerna (31), pasca operasi (10), restriksi cairan (1), dan syok (7).

\section{Pembahasan}

Status gizi terbanyak pasien saat awal masuk PICU adalah gizi kurang $(48,9 \%)$. Hal tersebut jauh lebih tinggi dibandingkan dengan data penelitian sebelumnya yang menyatakan bahwa saat masuk PICU pasien sudah mengalami malnutrisi, pada 15\%$25 \%$ kasus. ${ }^{1,5}$ Mehta dkk, ${ }^{2}$ dalam penelitian secara multisenter pada 31 PICU rumah sakit pendidikan, malnutrisi berat telah terjadi pada $30 \%$ pasien yang masuk PICU. Prevalensi malnutrisi yang tinggi sejak awal masuk PICU Anak FKUI RSCM berhubungan dengan tingkat ekonomi masyarakat Indonesia. Hal tersebut menyebabkan sebelum masuk PICU, anak sudah berada dalam kondisi kurang atau buruk. Selain itu, RS. Cipto Mangunkusumo merupakan rumah sakit pusat rujukan umum-pasien yang tidak dapat ditangani oleh rumah sakit lain-sehingga menyebabkan pasien datang sudah dalam kondisi yang buruk dan mengalami malnutrisi.

Pemberian nutrisi terbanyak dimulai pada hari ke-2. Hal tersebut terjadi karena pasien yang masuk ke PICU Anak, prioritas utama adalah menjaga stabilisasi susunan saraf pusat, respirasi, kardiovaskular, metabolik, dan hematologi sehingga pemberian nutrisi diberikan jika semua keadaan tersebut sudah stabil. Pemberian nutrisi hari pertama didapatkan 26,7\% pasien. Angka tersebut lebih rendah dari penelitan de Neff $\mathrm{dkk}^{1}$ yang mendapatkan pemberian nutrisi pada hari pertama $40 \%$ dan kedua $70 \%$.

Sementara itu, penelitian Mehta $\mathrm{dkk}^{2}$ menemukan $67 \%$ pasien menerima nutrisi enteral dalam 2 hari pertama. Rekomendasi ASPEN (American Society for parental and enteral nutrition) menyebutkan bahwa apabila tidak ada gangguan saluran cerna, pemberian nutrisi enteral harus diberikan sesegera mungkin. ${ }^{4}$ Stabilisasi pasien kadang tidak mudah sehingga memerlukan waktu yang lebih lama untuk memulai pemberian nutrisi. Pada hari ke-4, dua $(4,4 \%)$ pasien mulai mendapatkan pemberian nutrisi.

Pada $29(64,4 \%)$ pasien, lama rawat $<72$ jam. 
Pasien yang dirawat $\geq 72$ jam biasanya disebabkan karena ketidakstabilan pasca bedah, pasien leukemia dengan hiperleukositosis, dan pasien dengan gangguan neurologis seperti Guillan-Barre Syndrome (GBS) yang membutuhkan pemantauan ketat di PICU.

Pemberian kalori yang dihitung berdasarkan BMR ditambah dengan faktor stres membuat perhitungan kebutuhan nutrisi menjadi tidak mudah. Pada perhitungan BMR, digunakan data berat badan. Data berat badan sebenarnya tidak dapat digunakan ketika pasien mengalami edema atau dehidrasi (baik karena diare, muntah atau pemberian diuretikum) karena akan terjadi perubahan berat badan secara akut. Pada pasien dengan kondisi tersebut dipakai berat badan ideal untuk menghitung BMR. Perhitungan faktor stres dipakai dengan menggunakan nilai terkecil dari rentang yang ada. Dengan menghitung BMR ditambah dengan faktor stres, ditemukan bahwa underfeeding (pemberian $<90 \%$ kebutuhan) terjadi pada pemberian kalori 30 (66,7\%), protein 39 (86,67\%), dan lemak 27 (60\%) pasien. Hal tersebut hampir serupa dengan penelitian de Neff $\mathrm{dkk}^{1}$ dengan underfeeding terdapat pada $49,9 \%$ pasien yang diberi kalori, $84,6 \%$ pasien yang diberi protein dan $66 \%$ pasien yang diberi asupan lemak.

Asupan nutrisi yang kurang, terutama protein seperti yang telah dijelaskan di atas, akan menyebabkan balans negatif nitrogen dan berkurangnya masa otot, termasuk otot bantu nafas sehingga pasien sulit untuk diekstubasi. Mehta $\mathrm{dkk}^{2}$ menyebutkan pemberian protein $3 \mathrm{gram} / \mathrm{kg}$ berat badan/ hari akan mengganti protein yang turun akibat katabolisme tubuh.

Sebaliknya, terdapat overfeeding kalori, protein, dan lemak, beturut-turut pada $8(17,8 \%), 1(2,2 \%)$, dan $7(15,6 \%)$ dari 45 pasien. Hal tersebut terjadi karena pasien dapat diberikan nutrisi melampaui kebutuhan BMR-nya, terutama pasien dengan hiperleukositosis pada leukemia akut dan pasien dengan GBS. Pada 7 dari 45 pasien, dirawat hanya 1 hari di PICU Anak, tidak mendapat protein dan lemak sama sekali. Ketujuh pasien ini adalah pasien pasca bedah yang setelah stabilisasi selama 1 hari, lalu pindah ke bangsal.

Empat puluh lima pasien mendapatkan 127 peresepan kalori dan protein. Pada pemantauan selanjutnya, ternyata, didapatkan rencana pemberian nutrisi yang dituangkan dalam bentuk peresepan nutrisi yang tidak dapat diberikan seutuhnya pada pasien. Terdapat selisih antara peresepan nutrisi dan pemberian nutrisi yang sesungguhnya pada pasien. Selisih ini sebagian besar (124 dari 127 peresepan untuk kalori dan 97 dari 127 peresepan untuk protein) tidak lebih dari 30\%. Selisih ini terjadi akibat beberapa penyulit. Penyulit ini bisa terjadi lebih dari satu pada masingmasing pasien. Penyulit terbanyak adalah perdarahan saluran cerna diikuti dengan diare dan pasca operasi bedah gastrointestinal. Penyulit ini menyebabkan nutrisi harus diberikan secara parenteral.

Pemberian nutrisi parenteral mempunyai banyak efek samping. Selain itu, pemantauan pemberian nutrisi parenteral harus lebih ketat, terutama dalam hal memperhitungkan kebutuhan cairan per hari, kecepatan pemberian glukosa permenit, evaluasi kadar gula darah, elektrolit, fungsi hati, dan profil lipid.

\section{Kesimpulan}

Pada pasien dengan kondisi kritis, pemberian nutrisi merupakan salah satu target terapi anak yang dirawat di PICU, terutama anak yang sejak awal masuk mengalami gizi kurang atau buruk. Untuk memenuhi kebutuhan nutrisi, klinisi harus memperhitungkan kebutuhan energi beserta faktor stres yang menyertainya, perhitungan pemberian makronutrien, mengutamakan jalur oral atau enteral, terutama apabila tidak ditemukan kelainan saluran cerna. Terdapat selisih antara peresepan dan pemberian nutrisi yang disebabkan adanya penyulit sehingga nutrisi enteral tidak dapat diberikan. Hal tersebut menyebabkan underfeeding pada anak yang dirawat di PICU dan anak makin mengalami malnutrisi. Untuk mencegah terjadinya malnutrisi pada anak yang dirawat di PICU, perhitungan kebutuhan kalori, protein, dan lemak harus dilakukan secara cermat. Diperlukan kerjasama antara klinisi, perawat, dietisien, dan farmasi dalam suatu tim asuhan nutrisi pada pasien dengan kondisi kritis.

\section{Daftar pustaka}

1. De Neef M, Geukers VGM, Dral A, Lindeboom R, Sauerwein HP, Bos AP. Nutritional goal prescription and delivery in a pediatric intensive care unit. Clin Nutr 2008;27:65-71.

2. Mehta NM, Bechard LJ, Heyland DK. Nutritional practice and their relationship to clinical outcomes in critically ill children- an international multicenter cohort study. Crit Care Med 2012;40:2004-11. 
3. Billings CA, Coren CV, Fiordalisi I, Saavedra JM, Trapanotto V, Vasilescu A. Gastrointestinal disorders and nutrition. Dalam: Perkin RM, Fiordalisi I, Novotny WE, penyunting. The PICU book. World scientific, East Carolina University, USA;2012.h.357-65.

4. Mehta NM, Compher C. A.S.P.E.N. Clinical guidelines: nutrition support of the critically ill child. J Parenter
Enteral Nutr 2009;33:260-74.

5. Schofield W. Predicting basal metabolic rate, new standards and review of previous work. Human nutrition clinical nutrition 1985; Supp 1:5-41.

6. Sjarif DR, Nasar SS, Devaera Y, Tanjung CF. Asuhan nutrisi pediatric (pediatric nutrition care). Rekomendasi Ikatan Dokter Anak Indonesia. Jakarta: UKK Nutrisi dan penyakit metabolik; 2011.h.1-14. 